\title{
PENERAPAN PROGRAM APU PPT UNTUK MENCEGAH PENCUCIAN UANG DAN PENDANAAN TERORISME PADA INDUSTRI FINTECH
}

\author{
Febrina Annisa \\ Prima Resi Putri \\ Dosen Fakultas Hukum Universitas Bung Hatta \\ e-mail: febrina.annisa@bunghatta.ac.id
}

\begin{abstract}
ABSTRAK
Perkembangan teknologi terutama di bidang keuangan semakin maju dan berkembang. Salah satunya FinTech atau Financial Technology, yang di Indonesia sendiri baru mulai berkembang di tahun 2007, yang tentunya tidak menutup kemungkinan terjadinya risiko-risiko pencucian uang dan pendanaan terorisme. The FATF Recommendations meminta dan mewajibkan setiap negara untuk mengkriminalisasi segala bentuk pencucian uang dan pendanaan terorisme. Indonesia termasuk negara yang mempunyai komitmen penuh dalam mencegah dan memberantas pencucian uang dan pendanaan terorisme. Melalui penelitian ini penulis berusaha untuk menganalisa penerapan APU PPT untuk mencegah pencucian uang dan pendanaan terorisme sesuai dengan Undang-Undang Pencegahan dan Pemberantasan Tindak Pidana Pencucian Uang, Undang-Undang Pencegahan dan Pemberantasan Tindak Pidana Pendanaan Terorisme, POJK Nomor 77/POJK.01/2016 tentang POJK P2P Lendingdan POJK No. 12/POJK.01/2017 tentang Penerapan Program Anti Pencucian Uang dan Pencegahan Pendanaan Terorisme (APU PPT).
\end{abstract}

Kata Kunci: FinTech, pencucian uang, pendanaan terorisme.

\section{ABSTRACT}

The development of technology especially in financial sector, are more advanced and twin. One of them is, FinTech (Financial Technology), which in Indonesia began to develop in 2007, in this case Indonesia still has possibility in money laundering and financing of terrorism. The FATF Recommendations obliged each country to criminalize all forms of money laundering and terrorism financing. Indonesia shows its commitment in preventing and combating money laundering and financing of terrorism through APU PPT Program. This research is aim to analyze the applications of the APU PPT Program to prevent money laundering and financing of terrorism in accordance to Law Number 8 of 2010 concerning Prevention and Combating of Criminal Acts of Money Laundering, Law Number 9 of 2013 concerning Prevention and Combating of Criminal Acts of Terrorism Financing, POJK Number 77/POJK.01/2016 concerning P2P Lending and POJK Number 12/POJK.01/2017 concerning Implementation of the Anti-Money Laundering and Prevention of Terrorism Financing.

Keynotes: FinTech, money laundering, terrorist financing 


\section{PENDAHULUAN}

Dewasa ini, perkembangan teknologi tak dapat lagi kita bendung. Teknologi seperti sudah bagian dari kehidupan masyarakat moderen. Perkembangan teknologi ini terjadi disegala bidang ilmu pengetahuan dan industri, termasuk dalam industri finansial, yang lebih kita kenal dengan istilah FinTech atau Financial Technology.

FinTech muncul dari sebuah tuntutan kehidupan masyarakat moderen yang menuntut segala sesuatu harus serba cepat sehingga, mendorong perusahaan teknologi atau stake holder di bidang jasa keuangan menciptakan sebuah inovasi yang mampu mendukung setiap kebutuhan masyarakat moderen dalam hal jualbeli dan transaksi lainnya. Akhirnya, FinTech hadir sebagai sebuah solusi dalam bentuk layanan digital yang mampu melakukan transaksi pembayaran dan peminjaman secara "online" yang dapat diakses melalui "smart phone", contoh salah satu aplikasi yang akrab kita dengan adalah OVO dan Go-Pay.

Dengan bertumbuhnya masyarakat kelas menengah atas, Indonesia kini merupakan negara dengan penetrasi internet yang tinggi dan berfungsi sebagai lahan subur bagi pertumbuhan FinTech terutama pasar untuk pinjaman, kartu dan pembayaran. Saat ini, lebih dari 150 start-up FinTech ditemukan di Indonesia, meningkat 78 persen sejak tahun $2015^{1}$. Nilai pembiayaan FinTech di Indonesia dinilai terus naik dari tahun ke tahun, Pada 2016, nilai pembiayaannya berkisar Rp 190 triliun, sedangkan tahun 2017 setara dengan Rp 247, 65 triliun. Bahkan diprediksi nilai pembiayaan pada 2021 akan naik menjadi Rp 494 triliun $^{2}$.

Di tengah pesatnya pertumbuhan industri FinTech, banyak masyarakat yang tidak menyadari bahwa sangat mungkin untuk timbul modus-modus penyelundupan dana haram dalam bentuk tindak pidana pencucian uang (TPPU) yang berpotensi besar menyasar sektor FinTech ini, khususnya FinTech yang tidak terdaftar di otoritas negara, yaitu di Otoritas Jasa Keuangan (OJK).

Dalam rangka mengantisipasi modus pencucian uang, Financial Action Task Force (FATF) telah mengeluarkan 40 (empat puluh) rekomendasi terkait

1 Data yang diperoleh bersumber dari cekindo.com, Perkenalan Pada Gambaran Perkembangan Industri Fintech di Indonesia, ( https://www.cekindo.com/id/blog/industri-fintech ), terakhir diakses pada tanggal 8 September 2019

2 Ridwan Sanjaya, "Masa Depan Financial Technology (Unika Dalam Wacana Publik 2017 - 2018: Transformasi Inspiratif), hal. 15, Unika Soegijapranata. 
standar internasional di bidang pencucian uang dan pendanaan terorisme yang diadopsi oleh mayoritas yurisdiksi di dunia melalui pengawasan FATF-style Regional Bodies (FSRBs). FSRBs untuk negara-negara kawasan Asia Pasifik ditangani oleh Asia Pacific Group on Money Laundering (APG) ${ }^{3}$.

Berdasarkan The FATF Recommendation Number 1 on 2012 disebutkan bahwa setiap negara harus mengidentifikasi, menilai dan mengevaluasi adanya risiko TPPU dan risiko TPPT, dan harus mengambil tindakan, serta memutuskan otoritas mana yang mengkoordinasikan kegiatan penilaian atas risiko dan pendayagunaan sumber daya yang bertujuan untuk memastikan bahwa risiko yang ada telah diminimilisir secara efektif ${ }^{4}$. Sebagai bentuk nyata keseriusan dan komitmen Indonesia dalam menangani TPPU dan TPPT, maka pada tahun 2015 Indonesia telah menerbitkan dokumen National Risk Assessment (NRA). Dengan telah disusunnya NRA ini akan mudah untuk memetakan risiko pencucian uang yang terjadi di Indonesia, guna mendukung upaya meminimalisir risiko yang dimaksud dalam Rekomendasi FATF Nomor 1 Tahun $2012^{5}$.

Amerika Serikat (AS) telah mengambil tindakan hukum terhadap perusahaan FinTech yang tidak patuh terhadap ketentuan federal Anti-Money Laundering (AML). Tindakan tersebut diambil melalui otoritas pemeriksa keuangan AS, The Financial Crimes Enforcement Network (FinCEN) yang berada dibawah Departemen Keuangan. Sedangkan, di Indonesia melalui OJK telah memberhentikan operasional sebanyak 803 entitas FinTech ilegal, tetapi sayangnya hanya terbatas pada pemblokiran aktifitas perusahaan tersebut, dikarenakan belum adanya ketentuan pidana khusus di Indonesia yang mengatur mengenai sanksi pidana terhadap perusahaan FinTech ilegal.

Berdasarkan latar belakang tersebut, penulis berpendapat bahwa penelitian mengenai "PENERAPAN PROGRAM APU PPT UNTUK MENCEGAH PENCUCIAN UANG DAN PENDANAAN TERORISME PADA INDUSTRI FINTECH" merupakan hal yang sangat penting karena dapat diketahui

3 Hamalatul Qur'ani, "Meraba Potensi TPPU di Industri Fintech", (https://www.hukumonline.com/berita/baca/lt5c9c73ce3720d/meraba-potensi-tppu-di-industrifintech), terakhir diakses pada tanggal 12 November 2019.

4 International Standards on Combationg Money Laudering and The Financing of Terrorisme \& Proliferation (The FATF Recommendation), Updated June 2019, hal. 9.

${ }_{5}$ Tim Penyusun SRA, Penilaian Risiko Tindak PIdana Pencucian Uang Pada Sektor Jasa Keuangan Tahun 2017, Penerbit: Otoritas Jasa Keuangan, hal. 1. 
bagaimana besarnya ancaman TPPU terkait dengan semakin berkembangnya industri FinTech di Indonesia.

\section{PERMASALAHAN}

Dalam industri apapun yang menggunakan teknologi mempunyai kemungkinan-kemungkinan untuk terjadinya TPPU, terutama dalam industri FinTech, bilamana fungsi pemerintah sebagai pembuat kebijakan tidak berjalan sebagaimana mestinya. Oleh karena itu, dalam tulisan ini permasalahan yang akan dibahas adalah: bagaimana penerapan program APU PPT untuk mencegah TPPU dan TPPT pada Industri Fintech di Indonesia.

\section{METODE PENELITIAN}

Dalam menjawab permasalahan diatas, penulis menggunakan metode hukum normatif dengan menitikberatkan pada pendekatan konseptual (conceptual approach). Pendekatan konseptual biasa digunakan untuk menguraikan dan menganlisis permasalahan penelitian yang beranjak dari adanya kekosongan norma. Artinya dalam sistem hukum yang sedang berlaku tidak ada atau belum ada norma dari suatu peraturan perundang-undangan yang dapat diterapkan pada peristiwa hukum atau sengketa hukum konkret ${ }^{6}$.

\section{PEMBAHASAN}

\section{Perkembangan Industri FinTech di Indonesia}

Menurut FinTech Weekly, FinTech is a line of business based on using software to provide financial services. Financial Technology companies are generally startups founded with the purpose of disrupting incumbent financial systems and corporations that rely less on software?. Sedangkan menurut Financial Stability Board (FSB), FinTech adalah suatu bentuk inovasi finansial berbasis teknologi yang dapat menghasilkan model bisnis, aplikasi, proses atau

${ }^{6}$ I Made Pasek Diantha, Metodologi Penelitian Hukum Normatif dalam Justifikasi Teori Hukum, (Jakarta: Prenada Media Grup, 2017), hal. 159.

${ }^{7}$ Muliaman D. Hadad, Financial Technology (FinTech) di Indonesia, disampaikan pada Kuliah Umum tentang FinTech - IBS, Jakarta, 2 Juni 2017. 
produk baru dengan efek material terkait pada pasar keuangan, institusi dan penyedia layanan keuangan ${ }^{8}$.

Di Indonesia sendiri, FinTech bukanlah suatu hal yang baru, karena pada tahun 2007 sudah ada DOKU yang bergerak dibidang pelayanan jasa keuangan pertama di Indonesia. Untuk lebih jelasnya, berikut gambaran singkat perkembangan FinTech di Indonesia ${ }^{9}$ :

\begin{tabular}{|c|c|}
\hline 2007 & $\begin{array}{l}\text { Muncualnya DOKU sebagai startup FinTech pertama di Indonesia yang } \\
\text { bergerak di payment gateaway. DOKU adalah penyedia layanan } \\
\text { pembayaran elektronik dan manajemen risiko pertama di Indonesia mulai } \\
\text { dari jual, bayar, beli, kirim sampai pinjam. }\end{array}$ \\
\hline 2008 & $\begin{array}{l}\text { Munculnya model keuangan baru melalui perangkat lunak Bitcoin yang } \\
\text { digagas oleh Satoshi Nakamoto (Jepang). Pada tahun yang sama } \\
\text { pemerintah mengeluarkan Undang-undang Nomor } 11 \text { Tahun } 2008 \text { tentang } \\
\text { Informasi dan Transaksi Elektronik. }\end{array}$ \\
\hline 2009 & $\begin{array}{l}\text { Bank Indonesia mengeluarkan peraturan nomor 11/12/PBI/20090 tentang } \\
\text { Uang Elektronik (Electronic Money). }\end{array}$ \\
\hline 2010 & $\begin{array}{l}\text { Berdirinya Amartha, startup FinTech pertama yang bergerak di bidang } \\
\text { peer-to-peer lending (P2P). Amartha memiliki target khusus, yaitu UMKM } \\
\text { dengan meminjamkan dana sebesar tiga juta rupiah untuk memulai } \\
\text { usahanya. }\end{array}$ \\
\hline 2013 & $\begin{array}{l}\text { Berdirinya Bareksa, yaitu market place yang memungkinkan user dalam } \\
\text { jual-beli produk finansial reksa dana secara online. Berdiri juga } \\
\text { kitabisa.com, yaitu fintech yang bergerak di sektor crowdfunding. }\end{array}$ \\
\hline 2015 & $\begin{array}{l}\text { Berdirinya Asosiasi FinTech Indonesia (AFTECH). Pada tahun yang sama } \\
\text { Go-Jek mengeluakan dompet digital yang diberi nama dengan Go-Pay. }\end{array}$ \\
\hline 2016 & $\begin{array}{l}\text { Masuknya FinTech dari luar negeri ke Indonesia seperti True Money } \\
\text { (Thailand) serta Xfers dan FinAccel (Singapura). Pada tahun yang sama } \\
\text { OJK mengeluarkan aturan terkiat P2P Lending. }\end{array}$ \\
\hline 2017 & $\begin{array}{l}\text { Bank Indonesia melarang penggunaan Bitcoin dengan mengeluarkan } \\
\text { Peraturan BI Nomor } 19 / 12 / \mathrm{PBI} / 2017 \text { tentang Penyelenggaraan Teknologi }\end{array}$ \\
\hline
\end{tabular}

8 Abdul Rasyid, Sekilas Perkembangan FinTech di Indonesia, ( https://businesslaw.binus.ac.id/2019/03/19/sekilas-perkembangan-fintech-di-indonesial ), terakhir diakses pada tanggal 19 November 2019.

${ }^{9}$ Sri Adiningsih, Transformasi Ekonomi Berbasis Digital di Indonesia: Lahirnya Tren Baru Teknologi, Bisnis, Ekonomi dan Kebijakan di Indonesia, (Jakarta: Gramedia, 2019), hal. 91. 
Finansial.

Berdasarkan data yang diperoleh dari Asosiasi FinTech Indonesia dan OJK, pelaku FinTech di Indonesia masih didominasi oleh bisnis payment sebanyak 43\%, pinjaman 17\%, dan sisanya berbentuk agregator, crowdfunding dan lain-lain ${ }^{10}$. Sampai pada hari ini regulasi mengenai FinTech di Indonesia hanya diatur melalui Peraturan OJK No. 77/POJK.01/2016 tentang P2P Lending, Peraturan BI No. 19/12/PBI/2017 tentang Penyelenggaraan Teknologi Finansial, Peraturan OJK No. 12/POJK.01/2017 tentang Penerapan Program Anti Pencucian Uang dan Pencegahan Pendanaan Terorisme (APU PPT) dan Surat Edaran No. 047/SEOJK.04/2017 tentang Penerapan Program APU PPT di Sektor Pasar Modal. Sementara itu, risiko-risiko yang sangat besar dari perkembangan FinTech ini menuntut pemerintah untuk membuat regulasi khusus yang mengatur secara langsung mengenai FinTech terkait dengan TPPU dan TPPT berserta dengan sanksi pidana bagi pelakunya.

\section{Risiko TPPU dan TPPT Dalam Industri FinTech}

TPPU merupakan hal baru di Indonesia, karena baru dikenal pada tahun 2002 sejak diundangkannya UU Nomor 15 Tahun 2002 tentang TPPU. Setelah diundangkannya UU TPPU ini, barulah diketahui bahwa banyak perbuatan yang ternyata merupakan perbuatan pencucian uang. Namun, dalam pembuktiannya tidaklah mudah, dalam TPPU setiap satu perkara dihadapkan kepada dua jenis tindak pidana, yaitu tindak pidana pencucian uang itu sendiri dan tindak pidana semula (predicate crime) $)^{11}$.

Pencucian uang adalah suatu proses atau perbuatan yang bertujuan untuk menyembunyikan atau menyamarkan asal usul uang atau harta kekayaan yang diperoleh dari hasil tindak pidana yang kemudian diubah menjadi harta kekayaan

10 Op.Cit., Muliaman D. Hadad, Financial Technology (FinTech) di Indonesia, disampaikan pada Kuliah Umum tentang FinTech - IBS, Jakarta, 2 Juni 2017.

11 Tubagus Irman, Money Laundering: Hukum Pembuktian Pencucian Uang, (Jakarta: Gramedia, 2017), hal. 1. 
yang seolah-olah berasal dari kegiatan yang $\mathrm{sah}^{12}$. Dalam Black's Law Dictionary $^{13}$ dikemukakan money laundering diartikan sebagai berikut:

"Term used to describe investment or other transfer of money flowing from racekteering, drug transactions, and either illegal sources into legitimate channels so that its original source can not be traced."

Pencucian uang pada intinya melibatkan aset kekayaan yang disamarkan sehingga dapat digunakan tanpa terdeteksi, apalagi dengan semakin maraknya FinTech pencucian uang dapat dilakukan kapan saja. TPPU paling dominan dilakukan dengan menggunakan sistim keuangan. Saat ini sudah 1.773 penyelenggara FinTech lending ilegal yang ditutup oleh Satgas Waspada Investasi (SWI) dan 144 penyelenggara FinTech lending yang terdaftar/berizin di OJK ${ }^{14}$.

Maraknya FinTech yang tidak terdaftar dapat menjadi sasaran yang sangat rentan terhadap pencucian uang dan berbagai tindak pidana lainnya. Terlebih lagi belum adanya aturan yang secara khusus mengatur mengenai hal tersebut. Regulasi yang mengikat dan jelas sangat dibutuhkan dalam perkembangan hukum terkait dengat maraknya FinTech di Indonesia, agar pemerintah menjadi lebih arif dalam mencegah terjadinya pencucian uang yang akan menyebabkan kerugian besar bagi perekonomian negara.

Menurut Kamus Besar Bahasa Indonesia (KBBI), risiko dapat diartikan sebagai akibat yang kurang menyenangkan (merugikan, membahayakan) dari suatu perbuatan atau tindakan ${ }^{15}$. Dalam konteks pencucian uang dan pendanaan terorisme, risiko diartikan ${ }^{16}$ :

1) Pada tingkat nasional adalah suatu ancaman dan kerentanan yang disebabkan oleh pencucian uang dan pendanaan terorisme yang membahayakan banyak sistem keuangan nasional serta keselamatan dan keamanan nasional.

${ }^{12}$ Adrian Sutedi, Tindak Pidana Pencucian Uang, (Jakarta: Citra Aditya Bakti, 2008), hal. 12 .

${ }^{13}$ Henry Campbell Black, Black's Law Dictionary, Sixth Edition, (St. Paul Minn: West Publishing Co., 1991), hal. 611.

14 Mendi Rahmadi (Deputi Direktur Kantor OJK Provinsi Sumatera Barat), disampaikan pada Konferensi Nasional Hukum 1 tahun 2019 di Fakultas Hukum Universitas Bung Hatta Padang tanggal 23 November 2019.

${ }^{15}$ Kamus Besar Bahasa Indonesia (KBBI), ( https://kbbi.kemdikbud.go.id/entri/risiko ). terakhir diakses pada tanggal 20 Desember 2019.

${ }^{16}$ Tim Penyusun SRA Otoritas Jasa Keuangan (OJK), Penilaian Risiko Tindak Pidana Pencucian Uang pada Sektor Jasa Keuangan Tahun 2017, (Jakarta: Otoritas Jasa Keuangan, 2017), hal. 5. 
2) Pada tingkat Penyedia Jasa Keuangan (PJK) adalah ancaman dan kerentanan yang menempatkan PJK pada risiko dimana PJK digunakan sebagai sarana pencucian uang dan pendanaan terorisme.

Berdasarkan hasil identifikasi dan analisis risiko TPPU pada sektor perbankan adalah sebagai berikut ${ }^{17}$ :

1) Pejabat lembaga pemerintahan (eksekutif, legislatif dan yudikatif), pengusaha/wiraswasta (orang perseorangan), pengurus partai politik, dan korporasi menjadi nasabah yang berisiko tinggi dalam melakukan TPPU.

2) Transfer dana dalam negeri, layanan prioritas (wealth management), transfer dana dari dan ke luar negeri, safe deposit box dan correspondent banking menjadi produk/layanan yang berisiko tinggi digunakan sebagai sarana TPPU.

3) DKI Jakarta, Jawa Timur, Jawa Barat, Sumatera Utara, Banten dan Jawa Tengah menjadi provinsi yang paling berisiko terjadinya TPPU karena memiliki tingkat risiko tinggi.

4) Cash Deposit Machine (CDM) menjadi saluran distribusi (delivery channel) yang berisiko tinggi digunakan sebagai sarana transaksi untuk tujuan TPPU.

Pencucian uang juga memiliki beberapa keterkaitan dengan pola kejahatan yang terjadi berikutnya. Seringkali, pencucian uang merupakan alat bagi sekelompok orang untuk mentransfer arus keuangan yang bersifat kriminal. Salah satu organisasi kejahatan yang menjadi agregator dalam pencucian uang adalah organisasi terorisme. Financial Intelligent Unit (FIU) menjelaskan bahwa spekulasi tentang pendanaan bagi beberapa kelompok kejahatan mampu berawal dari tindak pidana pencucian uang benar adanya, termasuk transaksi keuangan mencurigakan ${ }^{18}$ yang berguna untuk mendanai kelompok terorisme. Terkait dengan pendanaan terorisme ${ }^{19}$ yang merupakan salah satu faktor utama dalam

${ }^{17}$ Ibid., hal. ix.

18 Pasal 1 angka 6 Undang-Undang Republik Indonesia Nomor 9 Tahun 2013 tentang Pencegahan dan Pemberantasan Tindak Pidana Pendanaan Terorisme, Transaksi keuangan mencurigakan terkait pendanaan terorisme adalah: (a). transaksi keuangan dengan maksud untuk digunakan dan/atau yang diketahui akan digunakan untuk melakukan tindak pidana terorism; (b). transaksi yang melibatkan Setiap Orang yang berdasarkan daftar terduga teroris dan organisasi teroris.

19 Pasal 1 angka 1 Undang-Undang Republik Indonesia Nomor 9 Tahun 2013 tentang Pencegahan dan Pemberantasan Tindak Pidana Pendanaan Terorisme yang dimaksud dengan pendanaan terorisme adalah segala perbuatan dalam rangka menyediakan, mengumpulkan, 
setiap aksi terorisme sehingga upaya penanggulangan tindak pidana terorisme harus diikuti dengan upaya pencegahan dan pemberantasan terhadap pendanaan terorisme.

Selain itu, Rekomendasi FATF Nomor 5 menyebutkan "countries should criminalise terrorist financing on the basis of the terrorist financing convention, and should criminalize not only the financing of terrorist acts but also the financing of terrorist organizations and individual terrorists even in the absence of a link to a specific terrorist act or acts. Countries should ensure that such offences are designated as money laundering predicate offences ${ }^{\text {"20 }}$..

Rumusan lengkap mengenai tindak pidana pendanaan terorisme disebutkan secara jelas Pasal 4 Undang-Undang Pencegahan dan Pemberantasan TPPT yakni "setiap orang yang dengan sengaja menyediakan, mengumpulkan, memberikan, atau meminjamkan dana, baik langsung maupun tidak langsung, dengan maksud digunakan seluruhnya atau sebagian untuk melalukan tindak pidana terorisme, organisasi teroris, atau teroris dipidana karena melakukan tindak pidana pendanaan terorisme dengan pidana penjara paling lama 15 (lima belas) tahun dan pidana denda paling banyak Rp 1.000.000.000,- (satu miliar rupiah)”.

Berdasarkan konsep penilaian risiko di atas dan sesuai panduan FATF, Tim NRA on Terrorist Financing telah menilai potensi risiko tindak pidana pendanaan terorisme di Indonesia dengan hasil sebagai berikut ${ }^{21}$ :

memberikan, atau meminjamkan Dana, baik langsung maupun tidak langsung, dengan maksud untuk digunakan untuk melakukan kegiatan terorisme, organisasi teroris, atau teroris.

${ }^{20}$ Tim NRA Indonesia Pusat Pelaporan dan Analisis Transaksi Keuangan (PPATK), Penilaian Risiko Indonesia Terhadap Tindak Pidana Pendanaan Terorisme Tahun 2015, (Jakarta: Pusat Pelaporan dan Analisis Transaksi Keuangan), hal. 4-5.

${ }^{21}$ Ibid., hal 21-22. 
a. Modus Pendanaan Teroris

\section{Modus Pendanaan Terorisme Berisiko Tinggi}

Periode 2011-2014

\begin{tabular}{|c|c|c|}
\hline \multirow{5}{*}{ No. } & \multirow{5}{*}{ Modus } & Nilai Risiko \\
\hline & & 3 s.d 5 = Risiko Rendah \\
\hline & & $>5$ s.d $7=$ Risiko \\
\hline & & Menengah \\
\hline & & $>7$ s.d $9=$ Risiko Tinggi \\
\hline & Pendanaan dalam negeri melalui sumbangan ke & \\
\hline 1. & $\begin{array}{l}\text { yayasan menggunakan instrumen uang tunai yang } \\
\text { digunakan untuk pengelolaan jaringan teroris. }\end{array}$ & 6.23 \\
\hline 2. & $\begin{array}{l}\text { Pendanaan dalam negeri melalui penyalahgunaan } \\
\text { dana yayasan menggunakan instrumen uang tunai } \\
\text { yang digunakan untuk pengelolaan jaringan teroris. }\end{array}$ & 6.18 \\
\hline 3. & $\begin{array}{l}\text { Pendanaan dalam negeri melalui berdagang/usaha } \\
\text { (barang/jasa) menggunakan instrumen uang tunai } \\
\text { yang digunakan untuk pengelolaan jaringan teroris. }\end{array}$ & 6.18 \\
\hline 4. & $\begin{array}{l}\text { Pendanaan dalam negeri melalui tindakan kriminal } \\
\text { menggunakan instrumen uang tunai yang digunakan } \\
\text { untuk pengelolaan jaringan teroris. }\end{array}$ & 6.11 \\
\hline 5. & $\begin{array}{l}\text { Pendanaan dalam negeri melalui penyalahgunaan } \\
\text { dana yayasan untuk membuka kegiatan usaha baru } \\
\text { (barang/jasa) yang hasil untuk pengelolaan jaringan } \\
\text { teroris. }\end{array}$ & 6.08 \\
\hline
\end{tabular}

\section{Sumber: PPATK}

b. Cara Pemindahan Dana Dari Pemilik Dana ke Pelaku Teroris

Berdasarkan penilaian aparat penegak hukum dan pelapor mengenai cara pemindahan dana teroris dari pemilik dana kepada anggota teroris dapat dilakukan melalui 4 (empat) cara, yaitu: melalui pembawaan uang tunai (cash smuggling), melalui pihak Penyedia Jasa Keuangan (PJK), melalui pihak Penyedia Barang dan Jasa (PBJ) dan melalui pemanfaatan bisnis legitimate 
atau bisnis baru. Hal penilaian ini dapat diperlihatkan pada tabel sebagai berikut $^{22}$ :

\section{Cara Pemindahan Dana Teroris Periode 2011 s/d 2014}

\begin{tabular}{|c|c|c|}
\hline No. & Cara Pemindahan Dana Teroris & $\begin{array}{l}\text { Nilai Risiko } \\
3 \text { s.d } 5=\text { Risiko Rendah } \\
>5 \text { s.d } 7=\text { Risiko Menengah } \\
>7 \text { s.d } 9=\text { Risiko Tinggi }\end{array}$ \\
\hline 1. & $\begin{array}{l}\text { Melalui sistem pembayaran elektronik } \\
\text { (menggunakan kartu), misalnya kartu } \\
\text { ATM, kartu kredit, kartu belanja. } \\
\text { - Melalui sistem pembayaran online } \\
\text { misalnya internet banking, mobile } \\
\text { banking. } \\
\text { - Melalui sistem pembayaran baru (New } \\
\text { Payment Method) misalnya virtual } \\
\text { currency, virtual account. }\end{array}$ & 6.60 \\
\hline 2. & $\begin{array}{l}\text { Melalui pembawaan uang tunai atau } \\
\text { instrumen sejenis di dalam negeri. } \\
\text { Melalui pembawaan uang tunai atau } \\
\text { instrumen sejenis lintas batas negara } \\
\text { (cash smuggling). }\end{array}$ & 6.51 \\
\hline 3. & $\begin{array}{l}\text { Melalui kegiatan usaha / bisnis yang legal dan } \\
\text { sudah berjalan maupun pembukaan kegiatan } \\
\text { usaha baru. }\end{array}$ & 6.40 \\
\hline 4. & Melalui pedagang perhiasan dan logam mulia. & 6.20 \\
\hline 5. & Melalui pedagang kendaraan bermotor. & 6.20 \\
\hline 6. & $\begin{array}{l}\text { Melalui kegiatan usaha Penukaran Valuta } \\
\text { Asing / KUPVA (money changer) }\end{array}$ & 5.26 \\
\hline
\end{tabular}

\section{Sumber: PPATK}

Penilaian risiko pendanaan terorime yang dilakukan oleh PPATK menunjukkan bahwa sarana pemindahan dana terorisme yang berisiko tinggi adalah melalui sistim pembayaran elektronik, sistim pembayaran online, sistim ataupun New Payment Method, melalui kegiatan usaha / bisnis, melalui pedagang perhiasan dan 
logam mulia, melalui pedagang kendaraan bermotor dan melalui kegiatan usaha penukaran valuta asing.

\section{Upaya Pemerintah dalam Mencegah TPPU dan TPPT di Industri FinTech}

Saat ini pemerintah sangat serius dalam menerapkan prinsip APUPPTsesuai dengan FATF Recommendations. FATF Recommendations menetapkan langkah-langkah penting yang harus diterapkan oleh setiap negara ${ }^{23}$ :

a. Mengidentifikasi risiko, dan mengembangkan kebijakan-kebijakan dan melakukan koordinasi domestik;

b. Memburu pencucian uang, pendanaan teroris dan pendanaan yang terkait;

c. Menerapkan langkah-langkah pencegahan untuk sektor keuangan dan sektor-sektor lain yang ditunjuk;

d. Membangun kekuatan dan tanggung jawab terhadap otoritas yang berwenang (seperti: menginvestigasi, penegakan hukum dan otoritas pengawas) dn langkah-langkah institusional lainnya;

e. Meningkatkan transparansi dan ketersediaan informasi bagi pihakpihak yang berkepentingan mengenai badan hukum dan pengaturannya; dan

f. Memfasilitasi kerjasama internasional.

Dalam The FATF Recommendations Number 1 seperti yang telah penulis jabarkan pada bab pendahuluan tulisan ini bahwa setiap negara mempunyai kewajiban untuk mencegah TPPU dan TPPU dengan berbagai cara. Kemudian, jika kita telusuri lebih dalam lagi, The FATF Recommendations juga meminta negara untuk mengkriminalisasi segala bentuk pendanaan terorisme. Hal ini tercantum dalam The FATF Recommendations, sebagai berikut:

a. Recommendation 5 (the criminalisation of terrorist financing); "Rekomendasi 5 (Kriminalisasi terhadap pendaan teroris)";

b. Recommendation 6 (targeted financial 5 actions related to terrorisme and terrorist financing); "Rekomendasi 6 (menargetkan 5 tindakan pendanaan yang terkait dengan terorisme dan pendanaan teroris)"; dan

\footnotetext{
${ }^{23}$ The FATF Recommendations, op.cit., hal. 6.
} 
c. Recommendation 8 (measures to prevent the misuse of non-profit organisations) "Rekomendasi 8 (langkah-langkah untuk mencegah penyalahgunaan organisasi-organisasi non-profit)".

Rekomendasi FATF terkait kriminalisasi pencucian uang ini sejalan dengan Pasal

3 (1) (b) Konvensi Wina Tahun 1988, Konvensi Strasbourg dan Konvensi Palermo. Mengenai kriminalisasi pencucian uang hasil kejahatan, Konvensi Palermo merumuskannya secara identik dengan Konvensi Wina 1988 dan Konvensi Strasbourg 1990. Perbedaannya terletak pada tindak pidana asal yang membuahkan hasil kejahatan. Sejak tahun 2016, Indonesia telah menerapkan langkah-langkah sebagai upaya pencegahan penyalahgunaan FinTech untuk TPPU dan TPPT, sebagai berikut:

1. Peraturan Otoritas Jasa Keuangan (POJK)

OJK mengeluarkan POJK Nomor 77/POJK.01/2016 tentang P2P Lending. Kemudian, POJK ini memiliki peraturan turunan yaitu Surat Edaran OJK (SEOJK) Nomor. 18/SEOJK/02/2017 tentang Tata Kelola dan Manajemen. Salah satu jenis FinTech yang diatur dalam kedua peraturan tersebut adalah P2P Lending. Pertimbangan OJK mengeluarkan POJK Nomor 77/POJK.01/2016 dan SEOJK Nomor 18/SEOJK/02/2017 karena OJK melihat urgensi hadirnya ketentuan yang mengatur FinTech pinjammeminjam, memperhatikan masih kuatnya budaya pinjam meminjam (utang) di masyarakat Indonesia dan skema $P 2 P$ Lending ini masing termasuk dalam lingkup kewenangan OJK dikarenakan perusahaan tersebut memberikan pelayanan jasa keuangan ${ }^{24}$.

2. Peraturan Bank Indonesia

BI sebagai regulator terhadap sistem pembayaran telah mengeluarkan peraturan terkait FinTech di Indonesia melalui PBI No. 19/12/PBI/2017 tentang Penyelenggaraan Teknologi Finansial dan PBI No. 18/40/PBI/2016 tentang Penyelenggaraan Pemrosesan Transaksi Pembayaran.

3. Kementerian Komunikasi dan Informatika Republik Indonesia, melalui:

24 Tim Penyusun Otoritas Jasa Keuangan (OJK), Perlindungan Konsumen Pada FinTech: Kajian Jasa Perlindungan Konsumen Sektor Jasa Keuangan, (Jakarta: Departemen Perlindungan Konsumen OJK, 2017), hal. 51. 
a. Undang-Undang Nomor 11 Tahun 2008 tentang Informasi dan Transaksi Elektronik.

b. Peraturan Menteri Komunikasi dan Informatika Republik Indonesia Nomor 4 Tahun 2016 tentang Sistem Manajemen Pengamanan Informasi.

c. Peraturan Menteri Komunikasi dan Informatika Republik Indonesia Nomor 20 Tahun 2016 tentang Perlindungan Data Pribadi Dalam Sistem Eletronik.

Peraturan-peraturan tersebut telah mewajibkan penyelenggara FinTech untuk menerapkan program APU PPT. Selain itu, keseriusan Indonesia dalam mencegah dan memberantas pencucian uang dan pendanaan terorisme ini juga dapat dilihat dalam UU Pencegahan dan Pemberantasan TPPT dan UU Pencegahan dan Pemberantasan TPPU.

\section{PENUTUP}

FinTech di Indonesia semakin berkembang seiring dengan kemajuan teknologi, khusus dibidang teknologi keuangan. Indonesia menjadi salah satu negara yang berinisiatif untuk menerapkan langkah-langkah pencegahan penyalahgunaan FinTech untuk TPPU dan TPPT dengan merujuk pada The FATF Recommendations. Keseriusan Indonesia ini dapat dilihat dari adanya UndangUndang Pencegahan dan Pemberantasan TPPT, Undang-Undang Pencegahan dan Pemberantasan TPPU, Undang-Undang ITE, POJK P2P Lending. Keseluruhan peraturan-peraturan ini telah mewajibkan setiap penyelenggara FinTech di Indonesia untuk menerapkan program APU PPT guna mencegah dan memberantas pencucian uang dan pendanaan terorisme. Penulis mengharapkan program APU PPT yang dicanangkan oleh pemerintah, maka setiap perusahaan FinTech di Indonesia wajib untuk melaksanakan program tersebut, dengan cara:

1. Setiap perusahaan FinTech wajib untuk mengenali secara mendalam mengenai calon nasabahnya sebelum melakukan transaksi sesuai dengan POJK Nomor 77 Tahun 2016 tentang Pinjam Meminjam Uang Berbasis Teknologi Informasi.

2. Perusahaan FinTech juga dapat melakukan pendeteksian terhadap dana yang dicurigai merupakan hasil dari transaksi pencucian uang dan/atau merupakan bagian dari pendanaan terorisme. 
3. Jika kecurigaan tersebut terbukti, perusahaan FinTech harus segara melaporkan kepada PPATK untuk ditindak lebih lanjut.

\section{DAFTAR PUSTAKA}

\section{Buku}

Adiningsih, Sri, Transformasi Ekonomi Berbasis Digital di Indonesia: Lahirnya Tren Baru Teknologi, Bisnis, Ekonomi dan Kebijakan di Indonesia, Jakarta: Gramedia, 2019.

Black, Henry Campbell, Black's Law Dictionary, Sixth Edition, St. Paul Minn: West Publishing Co., 1991.

Diantha, I Made Pasek, Metodologi Penelitian Hukum Normatif dalam Justifikasi Teori Hukum, Jakarta: Prenada Media Grup, 2017.

Irman, Tubagus, Money Laundering: Hukum Pembuktian Pencucian Uang, Jakarta: Gramedia, 2017.

Sutedi, Adrian, Tindak Pidana Pencucian Uang, Jakarta: Citra Aditya Bakti, 2008.

\section{Jurnal}

Hadad, Muliaman D., Financial Technology (FinTech) di Indonesia, disampaikan pada Kuliah Umum tentang FinTech - IBS, Jakarta, 2 Juni 2017.

International Standards on Combationg Money Laudering and The Financing of Terrorisme \& Proliferation (The FATF Recommendation), Updated June 2019.

Rahmadi, Mendi, (Deputi Direktur Kantor OJK Provinsi Sumatera Barat), disampaikan pada Konferensi Nasional Hukum 1 tahun 2019 di Fakultas Hukum Universitas Bung Hatta Padang tanggal 23 November 2019.

Sanjaya, Ridwan, Masa Depan Financial Technology (Unika Dalam Wacana Publik 2017 - 2018: Transformasi Inspiratif), Unika Soegijapranata.

Tim Penyusun SRA, Penilaian Risiko Tindak Pidana Pencucian Uang Pada Sektor Jasa Keuangan Tahun 2017, Penerbit: Otoritas Jasa Keuangan. 
Tim Penyusun SRA Otoritas Jasa Keuangan (OJK), Penilaian Risiko Tindak Pidana Pencucian Uang pada Sektor Jasa Keuangan Tahun 2017, (Jakarta: Otoritas Jasa Keuangan, 2017).

Tim NRA Indonesia Pusat Pelaporan dan Analisis Transaksi Keuangan (PPATK), Penilaian Risiko Indonesia Terhadap Tindak Pidana Pendanaan Terorisme Tahun 2015, Jakarta: Pusat Pelaporan dan Analisis Transaksi Keuangan.

Tim Penyusun Otoritas Jasa Keuangan (OJK), Perlindungan Konsumen Pada FinTech: Kajian Jasa Perlindungan Konsumen Sektor Jasa Keuangan, Jakarta: Departemen Perlindungan Konsumen OJK, 2017.

\section{Websites}

Rasyid, Abdul, Sekilas Perkembangan FinTech di Indonesia, ( https://businesslaw.binus.ac.id/2019/03/19/sekilas-perkembangan-fintech-di-indonesial ）, terakhir diakses pada tanggal 19 November 2019.

Data yang diperoleh bersumber dari cekindo.com, Perkenalan Pada Gambaran Perkembangan Industri Fintech di Indonesia, https://www.cekindo.com/id/blog/industri-fintech ), terakhir diakses pada tanggal 8 September 2019.

Qur'ani, Hamalatul, “Meraba Potensi TPPU di Industri Fintech", (https://www.hukumonline.com/berita/baca/lt5c9c73ce3720d/merabapotensi-tppu-di-industri-fintech), terakhir diakses pada tanggal 12 November 2019.

Kamus Besar Bahasa Indonesia (KBBI),

https://kbbi.kemdikbud.go.id/entri/risiko ), terakhir diakses pada tanggal 20 Desember 2019.

\section{Peraturan Perundang-undangan}

Indonesia, Undang-Undang Nomor 11 Tahun 2008 tentang Informasi dan Transaksi Elektronik.

Indonesia, Undang-Undang Nomor 15 Tahun 2002 tentang Tindak Pidana Pencucian Uang jo. Undang-Undang Nomor 8 Tahun 2010 tentang Pencegahan dan Pemberantasan Tindak Pidana Pencucian Uang. Indonesia, Undang-Undang Nomor 9 Tahun 2013 tentang Pencegahan dan Pemberantasan Tindak Pidana Terorisme. 
Peraturan Bank Indonesia No. 11/12/PBI/2009 tentang Uang Elektronik (Electronic Money).

Peraturan Bank Indonesia (PBI) No. 19/12/PBI/2017 tentang Penyelenggaraan Teknologi Finansial.

Peraturan Bank Indonesia (PBI) No. 18/40/PBI/2016 tentang Penyelenggaraan Pemrosesan Transaksi Pembayaran.

Peraturan Otoritas Jasa Keuangan (POJK) No. 77/POJK.01/2016 tentang Layanan Pinjam Meminjam Uang Berbasis Teknologi Informasin (P2P Lending).

Surat Edaran OJK (SEOJK) Nomor. 18/SEOJK/02/2017 tentang Tata Kelola dan Manajemen. 